\title{
Human resource management strategies for small territories: an alternative proposition
}

\author{
Godfrey Baldacchino \\ Workers' Participation Development Centre \& Islands and Small States Institute, University of Malta, Malta
}

\begin{abstract}
This paper tackles the issue of educational development from a somewhat different, and still under-explored, perspective: that of human resource management (HRM). This paper argues that small territories have, often blindly, accepted an 'industrial relations' (IR) framework that is much more at home in the formalistic, mass production and mass employment based, manufacturing economies of the industrialised world. While the future of 'IR' in these settings is also being called into question today, small territories have been hard put all along to apply their labour relations practice to the strictures of this theory. An inductive analysis of the human resource condition in small territories reveals rather a contextual disposition for empowerment and entrepreneurship - a critical component for successful HRM practice - which is often unacknowledged, let alone addressed in public policy. The paper identifies aspects of current industrial relations as well as educational practice that could be addressed in order to better tap the benefits of this different understanding of human resourcefulness. () 2001 Elsevier Science Ltd. All rights reserved.
\end{abstract}

Keywords: Educational policy; Small territories; Industrial relations; Human resource management

\section{Preamble}

It is only in the last few decades that a serious attempt has been made to explore the idiosyncrasies of small territories. This area of research was by definition non-existent until such a category of independent, sovereign units started taking their place on the world's geo-political map, albeit late in the epoch of decolonisation. The fascination of the small, often island, site and its fair share of associated glamour and myth have no doubt contributed to such locations becoming academic curios, loaded with stereotypes uncritically accepted by one and all. Useful comparative work,

E-mail address: gbal1@um.edu.mt (G. Baldacchino). inductively based on case material, has been dispelling these constructions and building in their stead a more solid, experientially grounded, understanding of the small world predicament. Such advances are more noticeable in areas such as public administration (Baker, 1992; Public Administration and Development, 1998), economic growth and development (Dommen and Hein, 1985; McKee and Tisdell, 1990; World Development, 1980, 1993) and tourism (Briguglio et al., 1996a,b; Lockhart and Drakakis-Smith, 1996).

But it is the area of educational planning and management in small states that is probably the most developed and best sustained of all these research fields. Under the aegis of such international institutions as the Commonwealth Secretariat and UNESCO's International Institute for 
Educational Planning, and thanks to such reputable international journals as Compare and Prospects, a fairly long tradition of scholarly publications has been produced. Notable amongst these are Atchoarena (1993), Bray and Packer (1993) and Bray and Steward (1998). The pioneer in this field is probably Norwell E. Harrigan who argued for a customised approach to educational development in small, often island, territories (Harrigan, 1972).

\subsection{This paper}

This paper hopes to build on this rich pedigree. It adopts a fairly common definition of what constitute 'small territories' within this literature namely, countries that are either politically sovereign states or else have a fair degree of jurisdictional autonomy; while smallness of size is taken on the basis of a resident population cut-off point of around 1.5 million.

The novelty of this paper lies mainly in its attempt to tackle the issue of educational development from a somewhat different, and still underexplored, perspective: that of human resource management (HRM). Discussions about educational planning and management in small territories have been promoted primarily by experts and practitioners who come from a solidly education background - mainly university professors of education as well as educational planners and officers in Ministries or Departments of Education. In the case of this particular article, the point of departure is the economy, the labour market setting and the centrality of a suitable human resource management policy that is sensitive to any specifics obtaining in small territories.

These specifics are likely to exist. This paper will argue that small territories have, often blindly, accepted an 'industrial relations' (IR) framework that is much more at home in the formalistic, mass production and mass employment based, manufacturing economies of the industrialised world. While the future of 'IR' in these settings is also being called into question today, small territories have been hard put all along to apply their labour relations practice to the strictures of this theory. An inductive analysis of the human resource condition in small territories reveals rather a contex- tual disposition for empowerment and entrepreneurship - a critical component for successful HRM practice - which is often unacknowledged, let alone addressed in public policy. The paper identifies aspects of current industrial relations as well as educational practice that could be addressed in order to better tap the benefits of this different understanding of human resourcefulness.

\section{The critical resource}

That the major resource of any particular organisation is, or lies in, its human endowment is a glib statement we may have heard all too often. In a world increasingly open and inevitably disposed towards global competition, organisations and firms are finding themselves sharing markets with adversaries who match, or exceed, their 'best practice' in terms of delivery times, quality levels and technological sophistication. All eyes therefore turn to the human resource department as that which may yet provide that crucial, critical edge and boost competitiveness to higher, dizzier levels.

Such quantum leaps are theoretically within reach with the deployment of effective human resource management practice in firms. HRM is both a philosophy and a technique. As a philosophy, it squarely confronts the labour force as a potential partner in the work process. It obliges owners and managers to look at employees as individuals who can be brought to bear as committed players in achieving organisational goals. This is best done by taking on board employees' own interests when charting overall, corporate objectives, making sure that the profits landed by firms are also accompanied by significant rewards to those who labour to make them happen. Critical among such rewards are programmes that flexibly address the education, training and development needs of personnel generally, at all levels of the organisational hierarchy. This is the technique of HRM, premised on the understanding that a customised approach to the needs and aspirations of each employee constitutes a tangible form of commitment to that person's well-being and job satisfaction, which in turn should readily translate into 
a winning, synergetic partnership with managers and investors. Human and intellectual capital are recognised as being just as vital to a firm as are financial and entrepreneurial capital. Such an enthusiastic commitment should, given other supports, also liberate the, often latent, creative forces of employees, placing still further, priceless human talent at the organisation's service. According to Krulis-Randa (1990, p. 136), HRM embodies the following five characteristics:

- A focus on horizontal authority and reduced hierarchy; a blurring of the rigid distinction between management and non-management;

- Wherever possible, responsibility for people management is devolved to line managers; the role of personnel professionals is to support and facilitate line management in this task, not to control it;

- Human resource planning is proactive and fused with corporate-level planning; human resource issues are treated strategically in an integrated manner;

- Employees are viewed as subjects with the potential for growth and development; such potential is to be identified and developed in line with the adaptive needs of the organisation;

- All employees, managers and managed, have a common interest in the success of the organisation and should become aware of, and committed to, common goals.

\section{Enter human resources}

The above philosophy and associated techniques would have been anathema a few years ago. Conceiving of workers as 'human resources' (HR) is a very recent trend. As Springer and Springer (1990, p. 41) suggest, the history of HRM may be said to have started when NCR Corporation established a separate personnel office in the 1890s. The term itself — HR — has been coined as recently as the Second World War; while 'human capital theory' came onto the scene in the 1960s (Hendry and Pettigrew, 1990). This should not come as a surprise because, until very recently, a firm's com- parative advantage was generally deemed to depend substantially on technology (as in more efficient production processes) rather than on any human resources strategy (Whipp, 1996). Furthermore, in a scenario where mass markets operated under fairly stable conditions, it was a 'Fordist', 'just-in-case' type of production regime that was hailed as superior, based on a routinisation of tasks and de-skilling of employees (Wood, 1982; Womack et al., 1990).

In this setting, traditional industrial relations emphasised a tripartite, consensual social partnership between state, labour and capital. This model - promulgated by such eminent proponents as Parsons (1952), Dunlop (1958) and Fox (1966), as well as such influential international bodies like the International Labour Organisation (Cox, 1977) - achieved world-wide legitimacy. This model may have been a ponderous and slow-moving machinery for building a labour-management rapport; it may have been a structure more at home in a condition of comfortable and secure market dominance; it may have been more at home in a context where management and workers were resigned to the understanding that industrial relations was a battlefield; where harmonious industrial relations were really only a fragile truce, a lull in an eternal and bitter conflict between 'them and us'.

Times have changed dramatically. Worker commitment and company loyalty have suddenly been 'discovered' as critical resources for superior competition (Peters and Waterman, 1982). The superiority of more flexible, 'just-in-time' production systems, with a high responsiveness to market signals, is now widely recognised (Monden, 1983). The pressure is now on for 'employee affairs' to graduate from a marginal department maintaining sickness, seniority, leave and disciplinary records to become strategically integrated with the overall business objectives of a firm (Robbins, 1983; Amaya, 1990). The warlike, 'us and them' IR metaphor is being replaced by that of the 'final frontier' and an invitation to take up the challenge of the adventure together (Dunn, 1990, my emphasis). Human Resource Management practices have been conscripted in order to transform traditional enemies into allies, and to transform 
low-trust employment contracts into high-trust, commitment-rich, partnership agreements (Fox, 1974; Fukuyama, 1995; Cohen-Rosenthal and Burton, 1993).

Territories are obliged to face challenges similar to those of discrete firms and organisations, albeit from a different perspective. In spite of the 'privatisation' of development, political and administrative structures continue to carry a major responsibility in maximising the competitiveness of their economies generally and of individual firms particularly. They do so primarily by means of deploying a number of jurisdictional instruments, while directing the necessary (mainly public) funding towards the fruition of their objectives. These include providing attractive conditions for foreign direct investment; ensuring efficient and user-friendly administrative structures; enacting appropriate labour legislation; and implementing suitable education and training strategies.

Recent decades have witnessed the attempts of a number of polities to come to grips with the need to move from an 'industrial relations' to a 'human resource management' configuration. Neo-liberal economic doctrines, accompanied by wide-ranging privatisation programmes and changes in labour legislation, have led to a decline in trade union membership and lobbying power; a fall-back in public sector employment; and marked increases in the flexibilisation of the job contract (e.g., Ferner and Hyman, 1997). Public policy has thus contributed to the emergence of a "new managerialism' at work, whereby professional senior executives have a larger discretion to manage the operations of firms and agencies, in both private and public sectors. The 'right to manage' (Goss, 1994, p. 5) finds ideological support in the growth of strategic human resource management, particularly in the United States (see Beer et al., 1984; Fombrun et al., 1984). Here, it is the professional manager alone who is deemed to enjoy the authority to handle organisational practices, has the background expertise to master its intricacies, and is willing and able to bear full accountability for all outcomes.

This situation may lead to an interesting paradox. While specific human resource management initiatives are addressed towards enhancing worker empowerment, it appears that other attempts seek to do the exact opposite — such as disarming workers from any legitimate role in decision-making they may have enjoyed, particularly through their collective representation (see Storey, 1985, p. 201). Such conflicting policies are bound to be noted by employees who would thus become disillusioned, and also more suspicious, of the pious intentions of human resource development (HRD): is it just another more sophisticated form of control after all (Sewell and Wilkinson, 1996)? Is pluralism, for all its weightiness, still preferable in the face of a sham unitarism (Legge, 1995)? Does 'good old' industrial relations read as more trustworthy than glitzy human resource management?

Small territories are not exempt from these same forces, tensions and searching questions. The local absence of economies of scale typically obliges these territories to orient their economies towards external markets (Fischer and Encontre, 1998); this structural feature fostered a sense of competitiveness which saved many of these economies from contemplating protectionism (see Milne, 1999). Their policy leaders too often declare that their major asset is the human resource, often in sharp contrast to the lack of any exploitable natural resources. To what extent, however, is this bland observation supported by actual policy? And in what way does the small-scale environment present a different challenge to the deployment of human resource strategy?

\section{Five domains}

A wide and critical reading of the experiences of various small territories suggests that at least five key domains highlight the distinctive nature of such a deployment. These collectively intimate that the value of the discrete and enterprising person in a small territory is more pronounced than elsewhere.

Firstly, 'person power' is enhanced thanks to the ease of achieving expertise and monopoly status. With the obligation to provide the same roles and services forthcoming from larger social units, individuals in small territories are more likely to operate as sole service providers. “...[I]n a small coun- 
try, it is easy to hit the limelight" (Bray and Fergus, 1986, pp. 94-95). The diversification of knowledge and specialisation of tasks that any small territory needs to accommodate implies that one person (or even parts thereof) equals the small-scale society's total sum requirement of expertise and skill in some particular fields (Bennell and Oxenham, 1983, p. 31). As soon as individuals develop even a modest edge in an area of knowledge, skill or service provision, they may proclaim themselves, or may find themselves proclaimed by others, as having authoritative standing. Such results substantially form the 'natural monopoly' which occurs in the small-scale site. There is a social hierarchy like anywhere else; but this has typically fewer intermediate rungs. Various specialisms remain vacant or undeclared, until recognised and colonised by enterprising individuals (Murray, 1985, p. 194; Boyce, 1991, p. 113; Peters and Sabaroche, 1991, p. 133; Bray, 1992, p. 150). The latter may amass a portfolio of such specialisms and may flexibly deploy now a set of these, now another, in response to changing demand (Carnegie, 1982, p. 13; Trouillot, 1988, p. 32). The cultivation of one's own indispensability - what Murray (1981, p. 254) has aptly called 'monument building' - is quite a rational strategy in such a context; indeed, it may even be spontaneous and unavoidable. Presumptuousness may also reap rewards because, frankly, there may not be anyone around locally to challenge one's bluff or fragile claim to authority (Kersell, 1985, pp. 376-377).

Secondly, such person power leads invariably to a personalisation of service provision. The loss of one individual could constitute a very serious loss because of non-substitutability (see Shand, 1980, p. 16; Lowenthal, 1987, p. 36). And the association of a service or skill with one, and just one, person means that individuals requiring that skill or service may easily bypass the legal-rational structure to satisfy their demands by directly accosting the provider (Reid, 1974, pp. 21-22; Kersell, 1992, p. 292). Thus, personalisation works against and erodes institutionalisation (Danns, 1980, p. 17, 30; Schahczenski, 1992, p. 38). This is a behaviour pattern that may be fuelled by both sides since this facilitates the build-up of a network of obligation; while ensuring that the service remains solidly a function of the person, not of the institution in which that person operates.

Thirdly, even in the context of a tripartite or bipartite industrial relations framework, the discrete identity of individuals in the context of labour-management bargaining cannot be discounted. In other societies, bargaining and negotiation may take place amongst labour, state and management leaders who may hardly ever meet and who would not know much about each other except for information related explicitly to their role in industrial relations. In small-scale settings, the social partners would be well known to each other; they are likely to meet over and over again in a variety of social and civic events; their dealings and relationships apart from those related to industrial relations will also be widely known or at least be easily available for public consumption and mutual scrutiny. Information about their families, friends, favourite haunts, political beliefs would be available in such territories because of a much lower threshold of privacy. As noted by Connell (1988, p. 5):

Social ties in island micro-states are so powerful and pervasive that anonymity, impersonal role relationships and informality are difficult to maintain.

Hence, it may prove impossible to engage in any labour-management debates, whether at a one-toone or at a national level, without a fair degree of data spill-over from other role sets in which the incumbents operate as social beings. The effect of these structural tendencies is that aspects of the personal and matters specific to the individual find their way into and colour what may elsewhere be fairly objective, focused and impersonal dealings. As vividly noted by Benedict (1967, p. 49):

Impersonal standards of efficiency, performance and integrity are modified by the myriad relationships connecting the individuals concerned.

Fourthly, one must keep in mind that the economic structure of small territories is typically more heavily dependent on small businesses, on service 
establishments, on family-owned and family-run firms (Baldacchino, 1993, Chapter 2). With increasing smallness of plant and of labour force, it is also likely that the more prevalent form of labour relations is skewed towards a unitarism where the owner-manager exercises undisputed control. The basis of compliance to such uncontested power is a person-specific loyalty and commitment to the boss. Scott et al. (1989, p. 91) argue:

Typically, the business is seen as his [sic] possession to do as he wishes - and especially where the owner/manager is also the founder. It is import to realise that, for many owner/managers, the business is essentially an extension of their ego.

With such an 'extended family' culture in operation, attempts at introducing 'industrial relations' - via, say, workers becoming trade union members - can be easily construed as an act of defiance, disloyalty and cultural sabotage; and would be therefore liable to retaliation, possibly via termination of employment (Baldacchino, 1999; Rainnie, 1985).

Fifthly and lastly, even amongst employees who operate in traditional, 'industrial relations' frameworks - as may occur in the public sector and in relatively large private enterprises, it is likely that a significant number exploit the imperfect competition and natural monopoly settings of a small market by branching out with their own specialist market services. In circumstances where specialisation is lucrative but where its demand is not necessarily regular and stable, occupational pluralism - having a multiple labour market orientation - is a viable strategy (see Comitas, 1963; Brookfield, 1975, p. 71; Baldacchino, 1995, p. 270). Equipped with such 'polyvalency', employees would therefore easily complement their wage or salary by some other economic activity that they would tend to carry out as selfemployed. The practice of self-employment is therefore even more widespread than may be initially recognised; and the orientation of the selfemployed as autonomous, enterprising and astute would carry a natural sympathy with a large segment of the population of the small territory.

These five tendencies point towards the same direction: the notion of employee empowerment takes on added meaning in the small-scale milieu. The flexible deployment of person power, de-institutionalisation and person-specificity in labour relations encounters and the legitimacy of unitarism in small firms as well as among employees who may be part-time self-employed, act collectively to enshrine and bolster the value of the discrete person.

\section{Discussion}

Such a conclusion raises at least two major concerns. First of all, it illustrates a condition that is in sharp contrast to received wisdom, highlighting the difference which may exist between imported "common sense" and home-grown "good sense" (Baldacchino and Greenwood, 1998). One should not be surprised to find out that practitioners in small territories have intuitively known all along that human resource management is the preferable, indeed the only possible, strategy in their smallscale environment. Yet, they may have been obliged somehow to take on board the ceremonies and dispositions of traditional industrial relations because such a 'best practice' has been handed down to them from colonial masters, role models or seasoned consultants. The failure to recognise the 'ecology' of small scale (Commonwealth Secretariat, 1986, p. 6) may lead to an unquestioned trans-location, and an equally bland acceptance, of what has been tried and tested in other, larger, social units.

There is nothing new in this observation. Many small territories are gripped by a "macro-state emulation syndrome" (Harrigan 1974, 1979); and their citizens continue to be encouraged to adopt a received wisdom, 'common sense' interpretation of labour management, just as they are encouraged to do on so many other policy issues. They are therefore often engrossed at adopting the tried and tested strategies and policies of others, diligently seeking ways and means of how to make their practice conform to what is expected from the 
given theory. The result is a stark realisation of a mismatch between actual and expected behaviour.

\subsection{Negation or acknowledgement?}

In the face of this mismatch, two general reactions are possible from policy-makers. Both call for bravery and leadership, although of a different kind. One is to dismiss the specifics of the small territory's experience, defending the imported precept in the face of the evidence. This stance may meet the approval of formal institutions and external significant others - such as aid donors or international organisations - but would be of precious little help to comprehend and manage the local situation. The second approach is to discard the given theory and construct a new one inductively, based on one's own experiences, including street wisdom. This would raise many eyebrows but might at least prove a useful exercise towards improved self-understanding.

Although this observation must be corroborated by empirical investigation, it appears valid to argue that part of the unrecognised 'ecology' of the small territory lies in its 'person power' (Farrugia, 1991): the towering stature of its inhabitants. Many individuals in small territories operate as flexible specialists, extracting positional advantages where possible from such a status. They cultivate, and expect, a personal twist to institutional processes, including industrial relations encounters; and readily dismiss these in their relatively sprawling small enterprise sector. The setting appears ripe for a devolution towards 'soft' organisations and a kind of 'self-employed society'. ${ }^{1}$ Becoming such 'well rounded' individuals constitutes a form of 'human resource development' rather distinct from management intentions. Peters and Waterman (1982, p. 201) unwittingly label this crafting of discretion as 'skunk works':

[Workers] were creating almost radical decentralisation and autonomy with its attendant overlap, messiness around the edges, lack of co-ordi-

\footnotetext{
${ }^{1}$ I am grateful to Geoffrey Bertram (Victoria University, New Zealand) for coining the term.
}

nation, internal competition, and somewhat chaotic conditions, in order to breed the entrepreneurial spirit. They had foresworn a measure of tidiness in order to achieve regular innovation.

Furthermore, such an expression of 'resourcefulness' may leave those professional management trained to expect strict conformity quite surprised and exasperated. Thompson and Ackroyd (1995, p. 616) capture this feeling thus:

The picture drawn is of workers active and innovative in attempts to survive their employment, recurrently breaking rules and actively renegotiating them on a continuous basis...

\subsection{Therapy or recognition?}

This leads to the consideration of a second, different concern. Assuming that one accepts and acknowledges this wider definition of human resourcefulness as accentuated and encouraged by the conditions of a small-scale territory, what policy measures are called for in order to best manage and direct this tendency? To what extent can and should 'tidiness' be laid aside in order to acknowledge and promote still more 'innovation'?

These are critical questions: is 'person power' intrinsically good or bad? Should policy measures be taken to mitigate, squash or exploit such a condition? Should personalisation and individuality be punished or rewarded? The choice lies between 'therapy' [weeding out the infectious and harmful discrepancy and restoring the "common sense", industrial relations regime] or 'recognition' [implying a non-judgemental approach to the condition of 'person power' and seeking instead to become a master of the game by exploiting, rather than challenging, the condition] (Baldacchino, 1997, pp. 170-173).

Some elements of 'person power' appear to clearly militate against the alleged proper functioning of organisations. The unorthodox behaviour pattern diagnosed above does not easily lend itself to a corporate set-up that assumes a strict inter-dependency of roles and functions, as would be expected in a legal-rational bureaucracy. This 
observation is not necessarily correct, however. Contemporary organisational theory has come to appreciate that there are useful variations to the classic organisational structure. Project-based work teams, lean management practices and web-structured, 'networked' firms are indeed even better suited to the turbulence expected from a changing environment. The discretion wielded by individuals in such structures is a crucial asset to the organisation's survival, rather than a threat to its formal efficiency (Burns and Stalker, 1961; Trist, 1980). What is otherwise dismissed as anarchism, peskiness and insubordination should become the mettle of a differently run, competitively superior, type of firm. We are here crafting a human resource strategy that puts individuals first and renders the organisation as the resource for those individuals' needs. Like professionals, such employees need to be "held on a very light rein; to be persuaded rather than commanded; influenced, cajoled or bargained with rather than managed" (Handy, 1990, p. 152).

\subsection{Implications for industrial relations}

The transition is not easy. Trade union organisations as well as managers bred in the traditional, 'personnel' mould will both instinctively feel threatened by such a development in the human resource field. Industrial Relations had given them predictable parameters in which to operate; where it was clearly the task of managers to control; and the task of trade union to react to such control. The new HR set-up now envisages a work situation where problem ownership is devolved and where increasingly empowered employees control their own actions. Various management cadres are indeed abolished. This does not mean that there will or need not be any scope for management or trade unionism in the new scenario, however. Both set-ups can enjoy a reformed responsibility: the first to facilitate, mentor and supervise the empowerment process; the second to ensure a fair and just distribution of its results.

Secondly, the effective functioning of a networked, web-patterned organisation depends considerably on the ability of its incumbents to take upon themselves a specific form of internal com- munications. Working in splendid isolation - as in the romanticised, heroic brand of self-employment - will not work in organisations, but must rather give way to a different form of accountability, discussion and reportage. Much of this, in turn, depends on the ability to work in, and through, teams. A high degree of co-ordination is crucial for web-structured firms to address the challenges of the market with 'disciplined dynamism'.

\subsection{Implications for educational reform}

To facilitate the transition to a human resourcedriven work environment, specific reforms may be necessary in the sphere of education and training. Small territories are already hard put to ensure both a domestic and an international relevance to their educational certificates (see Bray and Adam, this volume; Bray and Steward, 1998). The argument of this paper is now suggesting that they should go even further, boldly encouraging a personality development trajectory customised to the reality of their labour markets and their specific 'HR' challenges.

Many territories, small or not so small, continue to deploy an educational system that has been largely transplanted from that of their erstwhile colonial masters. A variety of reforms in many territories have sought to shift the orientation of this educational system in order to address the specific social and developmental needs of the host society and economy, moving away from other preferences that the system may have tended, even subtly, to promote. Therefore, a more inclusivist and less academically driven curriculum helps to shift the educational system away from an elitist path for a minority who would tend to be lost to the system anyway though a brain or skill drain; as well as dampen a discrimination in favour of white-collar, non-technical employment.

Many small societies - and their educational systems - continue to fail to acknowledge the large empowerment and entrepreneurial capacity that small scale endows them with. Indeed, educational systems may paradoxically work to stifle initiative and to encourage students to seek work in a traditional, wage/salary-earner status. An 
orientation towards rote and the reproduction (rather than creation or reconstitution) of knowledge; and the priority of certification as against education works out into a lower than average percentage of the self-employed labour force having gone through post-secondary or tertiary education (Baldacchino, 1998). The glamour of administrative employment, especially in the public service ever so weighty in many small territories, continues to draw away many high achievers. This state of affairs continues to burden self-employment with a lower social status; while cheating the sector from the intellectual capital that may help it become still more globally competitive.

Educational systems still also tend to encourage the deployment of individualistic, competitive skills. Individual discretion and competence can and should continue to be encouraged; but schools continue to emphasise individually based forms of assignment and assessment; while students fresh out of (especially post-secondary) school have been criticised by bosses and managers for demonstrating poor leadership, co-operative and followership skills. If the human resource endowment of the small-scale location is not to deteriorate into centrifugal anarchism - with the right hand not knowing what the left hand is doing (Van Vijfijken and Faber, 1994), education must somehow address the need to prepare tomorrow's workforce in this direction. The fostering of such 'professional employees' need not imply a poverty of team building and social skills. After all, challenges at school need not always be assumed to be never too complex for just one individual's talents.

Possibly, it may be the teachers themselves who provide the entrepreneurial role models that we are looking for in our educational systems. They are likely to be enterprising in their polyvalency, supplementing their teaching job with economic activities in which they engage from positions of autonomy, possibly even monopoly. Can, and should, the substance and challenge of such a particular labour market orientation be addressed headon in the classroom, in the context of social studies, business studies or economics lessons?

\section{Conclusion}

While there is general agreement that education has to respond to the changing needs of a country's social-economic development, the character of such a response remains the subject of perennial debate, a condition exacerbated by the high expectations stakeholders hold of education and its output. Small territories are not exempt from such tensions. While the stakeholders therein will also be pulling educational systems now this way, now the other, seeking an elusive balance between different social forces, the small territory appears to have a natural disposition towards rewarding empowerment and initiative; and this is one aspect of the 'ecology' of small scale that continues to remain unacknowledged. In such a scenario, it therefore often does not figure in the education debate at all. Meanwhile, human resource management strategies, like industrial relations, continue to be airlifted and parachuted to small polities from larger role models. Once again, the benefits of a different, home-grown, "good sense" approach to human resource development - the alternative proposition which drives the argument of this article - are totally lost. Will individuals in small territories prove entrepreneurial and innovative in spite of their educational systems or because of them?

\section{Acknowledgements}

I am grateful to Mark Bray, Antoinette Caruana and Michael Crossley for their comments on an earlier draft.

\section{References}

Amaya, T., 1990. Recent Trends in Human Resource Development. Japan Institute of Labour, Tokyo.

Atchoarena, D., 1993. Educational Strategies for Small Island States. UNESCO, International Institute for Educational Planning, Paris.

Baldacchino, G., 1993. Labouring in Lilliput: labour relations and images of smallness in developing microstates. Ph.D. thesis, University of Warwick, Coventry, UK. 
Baldacchino, G., 1995. Labour formation in small developing states: a conceptual review. Compare 25, 263-278.

Baldacchino, G., 1997. Global Tourism and Informal Labour Relations: The Small Scale Syndrome at Work. Mansell, London.

Baldacchino, G., 1998. The Graduating Workforce: Graduates on the Malta Labour Market. Gutenberg Press, Malta.

Baldacchino, G., 1999. A double dose of unitarism: employment relations in a small firm in a small island state. International Journal of Employment Studies 7, 103-121.

Baldacchino, G., Greenwood, R., 1998. Strategies of development for small island territories of the North Atlantic: common sense versus good sense. In: Competing Strategies for Socio-economic Development of Small Islands. University of Prince Edward Island, Institute of Island Studies, Canada, pp. 1-29.

Baker, R. (Ed.), 1992. Public Administration in Small and Island States. Kumarian Press, West Hertford, CT.

Beer, M., Spector, B., Lawrence, P., Quinn Mills, D., Walton, R. (Eds.), 1984. Managing Human Assets. The Free Press, New York

Benedict, B., 1967. Sociological aspects of smallness. In: Benedict, B. (Ed.) Problems of Smaller Territories. Athlone Press, London, pp. 45-55.

Bennell, P., Oxenham, J., 1983. Skills and qualifications for small island states. Labour and Society 8, 13-38.

Boyce, R., 1991. Barbados. In: Bray, M. (Ed.), Ministries of Education in Small States: Case Studies of Organisation and Management. Commonwealth Secretariat, London, pp. $106-122$.

Bray, M., 1992. The organisation and management of ministries of education in small states. In: Baker, R. (Ed.), Public Administration in Small and Island States. Kumarian Press, West Hertford, CT, pp. 144-156.

Bray, M., Fergus, H.E., 1986. The implications of size for educational development in small countries: Montserrat, a Caribbean case study. Compare 16, 91-102.

Bray, M., Packer, S., 1993. Education in Small States: Concepts, Challenges and Strategies. Pergamon, Oxford.

Bray, M., Steward, L. (Eds.), 1998. Examination Systems in Small States. Commonwealth Secretariat, London.

Briguglio, L., Archer, B., Jafari, J., Wall, G. (Eds.), 1996 a. Issues and Policies. Sustainable Tourism in Islands and Small States, vol. 1. Pinter, London.

Briguglio, L., Butler, R., Harrison, D., Leal Filho, W. (Eds.), 1996b. Case Studies. Sustainable Tourism in Islands and Small States, vol. 2. Pinter, London.

Briguglio, L., Kaminarides, J. (Eds.), 1993. Islands and Small States (special issue). World Development 21 (2).

Brookfield, H.C., 1975. Multum in Parvo: questions about diversity and diversification in small developing countries. In: Selwyn, P. (Ed.), Development Policy in Small Countries. Croom Helm, London, pp. 54-76.

Burns, T.R., Stalker, G.M., 1961. The Management of Innovation. Tavistock, London.

Carnegie, C.V., 1982. Strategic flexibility in the West Indies: a social psychology of Caribbean migration. Caribbean Review 11, 10-13, 54.

Cohen-Rosenthal, E., Burton, C.E., 1993. Mutual Gains: A Guide to Union-Management Co-operation. ILR Press, New York.

Comitas, L., 1963. Occupational multiplicity in rural Jamaica. In: Proceedings of the Annual Spring Meeting of the American Ethnological Society, Seattle, WA.

Commonwealth Secretariat, 1986. Educational development: the small states of the Commonwealth. In: Report of a panCommonwealth Experts Meeting, Mauritius, 1985. Commonwealth Secretariat, London.

Connell, J., 1988. Sovereignty and survival: island micro-states in the Third World. In: Research Monograph No. 3. University of Sydney, Department of Geography, Sydney.

Cox, R., 1977. Labour and hegemony. International Organization $31,385-424$

Danns, G.K., 1980. Leadership and corruption. An analysis of emergent post-colonial rule in the Caribbean. Transition 3, $9-41$.

Dommen, E.C. (Ed.), 1980. Islands (special issue). World Development 8 (12).

Dommen, E.C., Hein, P.L. (Eds.), 1985. States, Microstates and Islands. Croom Helm, London.

Dunlop, J.T., 1958. Industrial Relations Systems. Holt-Dryden, New York.

Dunn, S., 1990. Root metaphor in the old and new industrial relations. British Journal of Industrial Relations 28, 1-31.

Farrugia, C.J., 1991. Malta: educational development in a small island state. Prospects 21, 584-594.

Ferner, A., Hyman, R. (Eds.), 1997. Changing Industrial Relations in Europe. Blackwell, Oxford.

Fischer, G., Encontre, P., 1998. The economic disadvantages of island developing countries: problems of smallness, remoteness and diseconomies of scale. In: Baldacchino, G., Greenwood, R. (Eds.), Competing Strategies for Socio-economic Development of Small Islands. University of Prince Edward Island, Institute of Island Studies, Canada, pp. 69-88.

Fombrun, C., Tichy, N.M., Devanna, M.A., 1984. Strategic Human Resource Management. John Wiley, New York.

Fox, A., 1966. Industrial sociology and industrial relations. In: Royal Commission Research Paper No. 3. HMSO, London.

Fox, A., 1974. Beyond Contract: Work, Power and Trust Relations. Faber, London.

Fukuyama, F., 1995. Trust: The Social Virtues and The Creation of Prosperity. Penguin, London.

Goss, D., 1994. Principles of Human Resource Management. Routledge, London.

Handy, C., 1990. Inside Organisations. Penguin, London.

Harrigan, N.E., 1972. Higher education in the microstate: a theory of Raran society. Unpublished Ph.D. thesis, University of Pittsburgh, School of Education, Pittsburgh, PA.

Harrigan, N.E., 1974. The legacy of Caribbean history and tourism. Annals of Tourism Research 2, 13-25.

Harrigan, N.E., 1979. A theoretical analysis of the concept of micro-states: the Raran model. Paper presented at International Conference on the Politico-economic Development 
of Micro-states, Caribbean Research Institute, St Thomas, US Virgin Islands.

Hendry, C., Pettigrew, A., 1990. Human resource management: an agenda for the 1990s. International Journal of Human Resource Management 1, 17-43.

Kersell, J.E., 1985. The administration of Government in Bermuda. Public Administration and Development 5, 373385.

Kersell, J.E., 1992. An overview of the concept of smallness. In: Baker, R. (Ed.), Public Administration in Small and Island States. Kumarian Press, West Hertford, CT, pp. 290-302.

Krulis-Randa, J.S., 1990. Strategic human resource management in Europe after 1992. International Journal of Human Resource Management 1, 131-139.

Legge, K., 1995. Human Resource Management: The Rhetoric, The Realities. Macmillan, Basingstoke.

Lockhart, D.G., Drakakis-Smith, D., 1996. Island Tourism: Problems and Prospects. Mansell, London.

Lowenthal, D., 1987. Social features. In: Clarke, C.G., Payne, T. (Eds.), Politics, Security and Development in Small States. Allen and Unwin, London, pp. 26-49.

McKee, D.L., Tisdell, C.A., 1990. Developmental Issues in Small Island Economies. Praeger, New York.

Milne, D., 1999. Economic development in small jurisdictions. Bank of Valletta Review (Malta) 19, 25-51.

Monden, Y., 1983. Toyota Production System. Industrial Engineering and Management Press, Atlanta, GA.

Murray, D., 1981. Microstates: public administration for the small and beautiful. Public Administration and Development 1, 245-256.

Murray, D., 1985. Public administration in the micro-states of the Pacific. In: Dommen, E.C., Hein, P.L. (Eds.), States, Microstates and Islands. Croom Helm, London, pp. 185203.

Parsons, T., 1952. The Social System. Routledge and Kegan Paul, London.

Peters, M.E., Sabaroche, H.F., 1991. Dominica. In: Bray, M. (Ed.), Ministries of Education in Small States: Case Studies of Organisation and Management. Commonwealth Secretariat, London, pp. 123-138.

Peters, T., Waterman, R., 1982. In Search of Excellence: Lessons from America's Best Run Companies. Harper and Row, New York.

Rainnie, A., 1985. Is small beautiful? Industrial relations in small clothing firms. Sociology 19, 213-224.

Reid, G.L., 1974. The Impact of Very Small Size on the International Behaviour of Microstates. Sage, London.
Robbins, S.P., 1983. The theory Z organization from a powercontrol perspective. California Management Review 25, 67-75.

Schahczenski, J.J., 1992. Development administration in the small developing state. In: Baker, R. (Ed.), Public Administration in Small and Island States. Kumarian Press, West Hertford, CT, pp. 34-48.

Scott, M., Roberts, I., Holroyd, G., Sawbridge, D., 1989. Management and industrial relations in small firms. In: Research Paper No. 70. Department of Employment, London.

Sewell, G., Wilkinson, B., 1996. Empowerment or emasculation? Shopfloor surveillance in a total quality organisation. In: Blyton, P., Turnbull, P. (Eds.), Reassessing Human Resource Management, 3rd ed. Sage, London, pp. 97-115.

Shand, R.T., 1980. Island smallness: some definitions and implications. In: The island states of the Pacific and Indian oceans: anatomy of development, Monograph No. 23. Development Studies Centre, Australian National University, Canberra, pp. 3-20.

Springer, B., Springer, S., 1990. Human resource management in the US: celebrating its centenary. In: Pieper, R. (Ed.), Human Resource Management: An International Comparison. Walter de Gruyter, Berlin, pp. 41-60.

Storey, D., 1985. The means of management control. Sociology 19, 193-211.

Thompson, P., Ackroyd, S., 1995. All quiet on the workplace front? A critique of recent trends in British industrial sociology. Sociology 29, 615-633.

Trist, E., 1980. The environment and system-response capability. Futures 12, 113-127.

Trouillot, M.R., 1988. Peasants and Capital: Dominica in the World Economy. Johns Hopkins University Press, London.

Van Vijfijken, T.M., Faber, C.D., 1994. Does the right hand know what the left hand is doing? Management of sectoral linkages in the Eastern Caribbean states. Asian Journal of Public Administration 16, 87-108.

Warrington, E. (Ed.), 1998. Public Administration and Development 18 (2).

Whipp, R., 1996. Human resource management, competition and strategy: some productive tensions. In: Blyton, P., Turnbull, P. (Eds.), Reassessing Human Resource Management, 3rd ed. Sage, London, pp. 3-55.

Womack, J.P., Jones, D.T., Roos, D., 1990. The Machine that Changed the World. Rawson Associates, New York.

Wood, S. (Ed.), 1982. The Degradation of Work: Skill, Deskilling and the Labour Process. Hutchinson, London. 